\title{
Why technology adoption succeeds or fails: an exploration from the perspective of intra-organizational legitimacy
}

\author{
Min Ren
}

\author{
Correspondence: renmint@163.com \\ School of Sociology, Huazhong \\ University of Science and \\ Technology, Wuhan 430074, \\ People's Republic of China
}

\begin{abstract}
This paper constructs an intra-organizational legitimacy analysis framework to reveal the conditional mechanisms of technology adoption at the organization level. A retrospective look on a 9-year application process of ERP (Enterprise Resource Planning) in a Chinese state-owned enterprise shows how the application effects of an adopted technology fluctuate with changes to intra-organizational legitimacy, which itself is composed of performance legitimacy, task legitimacy, and value legitimacy. This research indicates that gaining sufficient legitimacy is one necessity for the success of technology adoption in organizations. Basically, performance legitimacy determines how far technologies can be transferred into the corporate sector. When a new technology adoption starts with performance uncertainty, task legitimacy ensures organizational resource investments that serve to initiate and accelerate technology adoption. Value legitimacy, on the other hand, ensures informal resource input, which preserves the technology during crises for future possible reuse and advances the application when used.
\end{abstract}

Keywords: Intra-organizational legitimacy, Performance legitimacy, Task legitimacy, Value legitimacy, State-owned enterprise of China, Technology adoption

\section{Introduction}

What are the key factors affecting an organization's adoption of an exogenously resourced technology? Researchers have three ways to answer this question, based essentially on different points of emphasis, including emphasizing technical factors (Davis 1986, 1989; Davis et al. 1989; Venkatesh 2000), technical-organizational match (for instance, Majchrzak and Paris 1995; Hong and Kim 2002), or organizational factors (Zhen et al. 2012; Li 2002; Sarker and Lee 2003; Yin and Chen, 2009; Huang 2010; Tan et al. 2015).

Emphasizing technological factors, TAM (technology acceptance model) and ID (innovation diffusion) focus on the technological characteristics implying that they determine the results of technology adoption, but this cannot explain the puzzle of why "one technology package has two outcomes" (Martinsons 2004). Researchers documenting the organizational perspective go too far, ignoring or even denying the technological factors that cause swinging from the technology imperative end to the technology powerless end, and they only vaguely consider organizational variables such

(c) The Author(s). 2019 Open Access This article is distributed under the terms of the Creative Commons Attribution 4.0 International License (http://creativecommons.org/licenses/by/4.0/), which permits unrestricted use, distribution, and reproduction in any medium, provided you give appropriate credit to the original author(s) and the source, provide a link to the Creative Commons license, and indicate if changes were made. 
as institutions, politics, or culture, which they mainly assumed were consistent and integrated. As for the technology-organization match perspective, matches are considered static or hard to change if they are not given.

Despite the existence, however, of considerable documented research as either static mechanisms mostly exploring quantitative causal relationships between concerned variables or dynamic mechanisms like qualitatively describing application processes for how political and institutional factors captured technology application, they categorized three dominant outcomes: success, partial failure, or total failure. But this three-way categorization did not cover all cases (Heeks 2002). For example, where should one place a "failure-followed-by-success" case? And this is without even mentioning innercase comparative research.

This paper investigates a case of ERP adoption in a Chinese state-owned company as complementary research. I draw data from three participant observations, more than 50 in-depth interviews, almost 100 questionnaires at a big Chinese state-owned company (pseudonym Da Company) from August to October in 2008, in January 2013, and in April 2016. The list of the key personnel for interviews was obtained through snowball sampling in which the important participants in the ERP adoption process served as the starting point. I conducted a follow-up investigation by phone of those who left due to job-hopping. All the names in this article are pseudonyms, too. The related public reports have been dug up as well.

Data analysis demonstrates how the organization and the adopted information technology and adoption were dynamically and mutually constructed in a changing environment, which influenced the intra-organizational legitimacy of technology in the adoptive organization and correspondingly affected the periodic results of technology adoption. If the intra-organizational legitimacy of an adopted technology is still changing, final stable results will not be obtained. The technology I studied is ERP, enterprise resource planning, an exogenously sourced information technology for the organization, which means it was totally new, and there was no recognition consensus when it was adopted by the organization (Qiu 2005).

This case is special for the ERP adoption research, for it is an exact "failure-followedby-success" information technology adoption case, and it is adequate for doing an inner-case comparison. Specifically speaking, the ERP adoption underwent a 9-year fluctuating process, from starting-up and almost being abandoned to restarting and then success-the four successive phases-from suspected failure to final success. This allows for an inner-case comparison study in which the inner organization environment at all stages are to a great extent comparable, making for a quasiexperiment for the researcher to detect what had been changed and how it connected with the rise and fall of periodic results in adoption project. From this, I conclude the conditional organizational mechanisms to answer the research question.

After a literature review, I construct a theoretical framework for the intraorganizational legitimacy of technology; then, I describe the case of the 9-year process of a Chinese state-owned enterprise implementing ERP. I then analyze the covariation between the intra-organizational legitimacy of technology and its periodical implementation results. In the end, I make conclusions and discussions. 


\section{Literature review}

Previous literature can be categorized into three ways to answer why information technology adoption fails or succeeds.

Some documents emphasize the effect of technological characteristics on technology adoption outcomes, such as cognitive usefulness and ease of use in TAM (Davis 1986, 1989; Davis et al. 1989; Venkatesh 2000), as well as the relative superiority, compatibility, complexity, testability, and observability of technologies in ID (Tatnall 2011). It seems plausible that technical application research should focus on technological features, but this does not explain why the same technology used in different organizations may lead to different outcomes-the so-called "one technology package has two (organizational) outcomes" puzzle (Martinsons 2004). Thus, technology adoption must be concerned with organizational factors or the relationships between technology and organization.

The research dealing with organization-side factors can be mainly divided into two perspectives. The first focuses on the effect of organizational managerial elements on technology adoption, including the material environment, like existing organizational IT capabilities/infrastructure (Holland and Light 1999; Yin and Chen, 2009) and nonmaterial administrative factors such as leadership, communication, and team empowerment (Sarker and Lee 2003; Ke and Wei 2008). The second explores the impact of wider-perspective factors on technology implementation, such as organizational management strategies (Aladwani 2001; Yusuf et al. 2004), organizational culture (Davison 2002; Ke and Wei 2008; Jones et al. 2006; Zhen et al. 2012), politics within organizations (Skok and Legge 2002, Tan et al. 2015), and the institutional environment where the organization is embedded (Huang 2010; Seo 2013), and it is usually inclined to explore how such factors hindered technology implementation.

As to the relationship between organizations and technology in technology adoption, there also exist two perspectives. First is the static O-T match, focusing on to what extent the requirements of information technology (e.g., ERP) for an organization are met from the existing organizational technological data basis, user interface friendliness to administrative process match (Zhang 2009), as well as organizational structures accommodation (Wang 2009). The concept of "match" implies meeting the requirements between technology and the adopting organization, and it allows for minor adjustments on the organizational side and great changes on the technological side. So if there is no match, technology will be resisted by an organization (Hong and Kim 2002; Rajapakse and Seddon 2005), leading to adoption failure (Heeks 2002). Second, a dynamic interaction mechanism is constructed mainly from a sociological perspective. This tradition started with Barley's research (Barley 1986) applying structuration theory to CT scanner adoption in two hospitals, after which a structural model of technology use was developed (Orlikowski 1992). Later, Qiu (2005) developed a mutual-structuring mechanism by excluding contingency traits.

Most related literature comes from management, including information systems management and organization management (Finney and Corbett 2007). Compared to the management discipline that solves specific management problems, the sociology of technology explores deeper, more profound and holistic abstract mechanisms; management science tries to obtain the best practice for technology implementation, while sociology is more interested in complex practical operations. For example, the former 
usually assumes that the benefits or culture of an organization are integrated, while sociology always sees political and fragmented-even conflicting-interaction. For example, information technology adoption is based on institutional logic rather than efficiency logic (Huang 2010), and organizational change is not efficiency-improvement oriented but acts upon the logic of interests and power (Tan et al. 2015). Compared to management and information science, sociological literature has been scarce, and its research issues are very limited (Qiu 2017). For some reasons, since the 1990s, there have been no substantive breakthroughs in the field (Zhang 2009), with sociology gradually becoming even more marginal (Zammuto et al. 2007).

To summarize the sociological point of view, it emphasizes that, first, technology is essentially regarded as a tool to reveal the operational logic of an organization. Second, technology adoption is the input of technology as well as the input of a specific organizational structure. New technology usually conflicts fiercely with existing formal structures, managerial or technical, of the adopting organization. The existing research leaves some gaps, however. For example, first, when technology and an organization fiercely conflict in structure, the technology is sometimes completely repelled from the organization, just as any other common project fails in an organization; but in reality the conflicts-some quite fierce-between technology and organizations do not necessarily lead to a failure of the technology's adoption. Examples of this are common; so what exactly might support technology to survive the violent mutation process of adoption? Second, existing literature revealing the logic of institutions, interests, and power in organizations against technology cannot explain why the success rate of information technology adoption continues to rise. Obviously, in the field of technology adoption research, the logic of efficiency has not attracted as much sociological attention as it deserves. When organizations are treated as institutionalized puppets, the rationality of organizations and the pursuit of their goals are discarded from research in sociologists' eyes. We do not think this is appropriate to explain organizational activities, especially for technology adoption in business organizations, which are essentially as rational as possible in organizing resources in pursuit of performance goals. As a sociologist, it may be more legitimate to explore the idea of efficiency rather than measurable efficiency. In this case, I probe how people consider potential efficiency at various times during the technology adoption process. Third, when the operations of an organization are simplified to a power contention, the members of the organization are assumed to be self-beneficiaries. It is as though they never consider the interests of the organization. Is this an over correction of the "organization-socialized people" hypothesis from the classical stage of organization research?

Therefore this study attempts to be complementary and fill these research gaps. From a sociological perspective, I explore how organizational members' recognition of technology affects technology adoption results, including failure and success.

The adoption of complex, new technology at an organization is always highly uncertain and risky in terms of its success, and it is mostly adopted with an expectation for performance improvements, especially at businesses. Considering the gap between an administrative order and the real operations of an organization, it is reasonable to say that the subjective validity-that is, people's belief and recognition-of the adopted technology is essential for the technology's implementation before its performance promise comes fully true. This forms the direct environment for the technology's 
implementation, which can be conceptualized as the legitimacy of the technology within an organization. It is necessary to explore this issue, for people's understanding and support of new things are directly related to their ability to mobilize resources (Bergek et al. 2008a, 2008b; Hekkert et al. 2007; Rao 2002). And sufficient resource input is of utmost importance for the survival of an adopted technology in an organization (Markard et al. 2016). The internal legitimacy of an organization provides cognitive and attitude-based support, which affects the resources procured by organizational members in their activities (Human and Provan 2000).

For a long time, however, the issue of the legitimacy of new technologies within organizations has been neglected by academics. This is probably related to academic inheritance, as legitimacy analyses are always used to study the macro-level of organization-environment relations. Legitimacy has traditionally been used to refer to the compatibility between organizations and the environment (laws, norms, values, beliefs, practices, expectations, etc.), but legitimacy is itself a strongly explanatory concept (Gao 2000), partly due to the vagueness and richness of its meaning. Legitimacy is assessment according to certain standards usually defined as a set of constructed norms, values, beliefs, and practices (Scott 2008; Suchman 1995) or it is defined as something that has a collective basis making it recognizable, recognized, or accepted (Gao 2000). Norms, values, convictions, and a basis refer specifically to different things according to specific research objects and research situations, which allows the interpretative power of legitimacy to be widely used in various fields of politics, sociology, anthropology, histology, etc. Such research is mainly confined to the macro or meso research levels.

Some scholars have explored or mentioned technology's intra-organizational legitimacy (Brown 1995, 1998; Qiu 2005; Huang 2010), but empirical research has been rare. Brown $(1995,1998)$ reveals how technology supporters manipulate the symbolic micropolitical process of technology's organizational legitimacy. The problems, however, that have not yet been discussed are, first, how the organizational legitimacy of technology adoption is assumed to exist without question; second, no research has been conducted on the classification of organizational legitimacy; and third, organizational understanding of technology has been reduced to the redistribution of benefits and power, and technology's significance in promoting organizational performance has never been explored.

Based on the above context, the question in this paper is whether the legitimacy of technology in the adopting organization affects technology adoption. If yes, why and how? What are the main forms of intra-organizational legitimacy for technology, and what are the possible mechanisms? This article explores the adoption of technology from the perspectives of the members of an organization, emphasizing how the members' understanding of technology matters but is not simply bounded to their awareness of intra-organizational politics, as sociological scholars always emphasized before.

Regarding legitimacy, I combine existing literature with my interviews of managers and key system users in organizations on their interpretation of the adopted technology-ERP in this case-to conclude three interpretative categories: performance legitimacy, task legitimacy, and value legitimacy. I do this to explore these legitimacy issues in technology adoption, including how technical performance legitimacy, task legitimacy, and value legitimacy affect organizational effectiveness under different conditions. 


\section{Three forms of intra-organizational legitimacy for technology}

Organization legitimacy is related to multiple subjects, who assesses and who admits. Internal and external evaluation of organizational legitimacy (Suchman 1995; Human and Provan 2000) correspondingly produce internal legitimacy and external legitimacy, where external legitimacy refers to the extent to which organizations are accepted in the social environment, and internal legitimacy is the degree to which an organization is accepted by its own members (Human and Provan 2000). The existing classification of organizational legitimacy implies two dimensions, who evaluates and the evaluation standards. For example, Suchman (1995) classifies the legitimacy of organizations into three categories: (a) pragmatic legitimacy based on the practicality of the self-interest calculations of stakeholders, (b) moral legitimacy referring to the normative suitability of mass judgment, and (c) cognitive legitimacy based on the public's perceived cognition. We cross-evaluate the subject (external observer or internal observer) and its assessment activities (examining the organization's external activities or activities within the organization) to propose a classification framework with two dimensions: (1) external observers assess organizational environment-oriented activities according to the community's expectation to gain external legitimacy (Ex-I), such as corporate social responsibility issues; (2) external observers assess the compatibility of internal activities and social norms defining the accuracy concerning the internal organizational operations to get external legitimacy (Ex-II), such as outsiders observing whether an organization, e.g., a hospital, performs professionally, or evaluating the legitimacy of management activities (moral or legal, etc.) within an organization (Ruef and Scott 1998); (3) internal observers assess outside-oriented organizational activities to produce internal legitimacy (In-I), which affects the general loyalty of organizational members to their organization and is particularly important for organizations that are in their infancy or periods of crisis; (4) internal observers refer to the norms and values of organizations to examine the internal legitimacy (In-II) of specific organizational activities, like that of new technology adoption, the extent to which affects resource-input decisions. This study focuses on the fourth category of legitimacy-specifically speaking, intra-organizational legitimacy of a technology in an adopting organization.

Regarding legitimacy, there is no uniform standard for investigators to choose dimensions of analysis, and thus it is instead based on specific research proposals and theories (Wang and Zhang 2012). This study defines a theoretical framework for intraorganizational legitimacy of an adopted technology into three forms: performance legitimacy, task legitimacy, and value legitimacy. They correspond to user assessments and acceptance of technology regarding (a) its hard ability to promote the performance of the organization, (b) its administrative qualifications to consume organizational resources as a sufficiently important organizational task, and (c) its compatibility with the organization's future development.

\section{Performance legitimacy}

Performance legitimacy refers to subjective technical significance rather than an objective performance evaluation of the technology. Thus, performance in this study is not an objective measure of performance, but rather an understanding of it. In practice, there always exists a gap between users' "subjective" judgments and "objective" 
professional evaluations, as common users seldom use professional tools when evaluating but use, instead, their "feelings." In addition, their judgments are mixed with secret conflicts of interest and power machinations.

As some scholars have pointed out, the legitimacy of technology in an organization stems first and foremost from its contribution to organizational performance, which means the technological capabilities of a technology determine its acceptance or rejection in the long run (Grint and Woolgar 1997). Performance legitimacy is based on the consensus of organizational members on the improvement of the organization's performance by the adopted technology. It has no single connotation (Ruef and Scott 1998; Yang and Zhao 2013; Zhang and Zhu 2016) but is all about pragmatism and interests. The core is to assess the indicators of performance, such as whether the technology can improve organizational efficiency, how much it can improve, to what extent it will cut costs, etc. This subjective assessment is what we call performance legitimacy. It is similar to the practical legitimacy of Suchman (1995) in that it emphasizes the perceptions and attitudes towards (organization or individual) interests, and as a subjective assessment consensus, it forms a supportive power exerting an institutional effect on organizational behavior. The difference is that I focus on internal legitimacy, in which assessors are from the inside, while Suchman (1995) discusses inner legitimacy on the organizational level and mainly defined by the system/institution from the outside, as had been traditionally done in organizational legitimacy studies.

Performance legitimacy of new technologies from insiders often involves assessments at two levels: external performance evaluations and performance predictions in the adopting organization. This means that insider recognition of technology performance is not limited to within organizations but is also affected by the technology's reputation in the external technology market as well as other users' perceptions, especially those in equivalent positions in industry market structures. The former, such as whether the technology industry itself is mature, ranks the selected technology in the supplier market, its successful adoption rate or its influential, successful use-cases in the market, etc., and it is decided by outside user word-of-mouth. The latter, such as whether the technology is suitable for an organization, its cost-benefit ratio, etc., is determined by users in the organization. Both constitute the performance legitimacy of the adopted technology. External performance legitimacy helps determine whether an organization adopts a technology, answering the question of why brand new technologies can be introduced into a performance-minded enterprise organization with their high inherent uncertainty and risk. Their level of external legitimacy also affects the possible room in which they gain internal legitimacy. The higher their external performance legitimacy is, the longer organizational members tolerate their non-performance periods; likewise, their will to endure technical problems during application will be higher. The more innovative a technology is, the more its internal performance prediction relies on external information. In the case of this research, when ERP was adopted, the whole integrated management software industry was quite new to the Chinese market. The adopting company had to rely heavily on external performance legitimacy for reference to decide whether or not to adopt the technology. And later, during a time of crisis, it used performance legitimacy to decide whether or not to keep the application going. We have to say that this paper attempts to limit legitimacy within organizations, but one can never completely rule out the discussion of external technological legitimacy. 


\section{Task legitimacy}

Task legitimacy represents to what extent hierarchical authority defines the technology as a necessary, compulsory organizational task, and how well the technology can use organizational resources. It legitimizes the technology to force organization members to change. Task legitimacy is mandatory within an organization. It comes from administrative organizational power, and it relies on top-down organizational authority.

Organizational resources are always limited, and organizational members shift resources to organizational tasks that are defined as "required" or a "must," leaving aside organizational tasks that are relatively optional. Innovative technology adoption are bound to change the behavior of the members of an organization. If the task of using a technology is legitimate enough, the members of an organization will work hard to adapt to the new situation instead of slacking off. If it is not legitimate enough, however, they will tend to resist the necessary changes. If accompanied by a loss of one's own interests, the technology implementation problem will be used as a tool for bargaining with managers at different levels. "They will say it is not because I have no will to use this technology but rather that it is the technology's severe problems that hinder its use" (Quiren 0808). ${ }^{1}$ Legitimacy as a task in this case is mainly reflected through three indicators. First is the support from the highest decision-makers, reflected in their open supportive statements, or vice versa. Second are the status fluctuations of the informatization team in charge of the adoption of the information technology. Third are size changes of the team in terms of expansion or contraction. The latter two objective indicators corroborate the previous subjective indicator.

\section{Value legitimacy}

This is a firm belief in the necessity of a technology coming from organizational members' recognition of the technology as satisfying the company's long-term benefit. It includes their loyalty, responsibility, and sense of mission, which all propel them to do the right things for the organization, even at personal risk. Organization members recognize the adoption of the technology as the trend of the times, believing it to be of great significance for the organization's future development, thus forming their strong belief that the organization must inevitably adopt the technology. This makes them a strong supportive power of technology adoption and implementation. This form of legitimacy is called value legitimacy because of its implication of conviction. It is essentially derived from Weber's theory of value-rational action, emphasizing that organizational members are also value-rational agents. It is a mixture of the cognitive legitimacy and moral legitimacy of Suchman (1995), that is, cognition emphasizes rationality, and professional technicians, overlooking short-term and observable performance considerations, look far ahead upon the strategic significance of the advanced

\footnotetext{
${ }^{1}$ Organizational decisions define the direction of organizational attention. More or less, there is always a gap between organizational decisions and executions. And the decision-makers' decisions are not independent of other managers or key employees, but are instead embedded in them, relying on the latter's feedbacks to be aware of where the decisions go. Objectively, this is the organization's correction mechanism, providing space for bargaining between the executors and the performers. This negotiable leeway is also related to the risk inherent in the decision itself and the decision-makers' confidence in the decision. The higher the risk involved in the decision, and the less confident the decision-makers are, the more the decision-making correction depends on feedback from executors and task performers, the bigger the bargaining space there would be for executors and performers, and the more likely the decision is to be modified later in the execution process. The adoption of very innovative technologies is a typical case of this.
} 
technology for the organization's future, which causes them to believe in the rationality of using technology at great cost. Moreover, the technicians' loyalty to the organization gives them the strength to stick to their professional judgment, and the higher their loyalty for their organization, the more likely they are to adhere to their professional understanding, even considering it at the moral (value) level. This in turn drives them to invest informal organizational resources and even personal resources in the technology's application. As an informal, valuable, and still powerful organizational resource for legitimacy, value legitimacy has been neglected by researchers so far. In this case, we conduct a discourse analysis of the relevant actor's ERP evaluation of its correlation with the future of organizations to determine whether he harbors value legitimacy.

\section{The relationship and a comparison of the three dimensions}

Objectives define organizational actions. They are related to the type of organizationin this case, a business-its distinct performance goals, the original intent for adopting the technology in question, and the efficiency dispute over adopting the technology, etc. All of these considerations indicate that performance legitimacy is essential, as it is the foundation of the overall intra-organizational legitimacy of technologies. The performance of the technology is, however, always uncertain until it is successfully used, which is a common reason for the twists and turns in the promotion of technology application. The legitimacy of the task stemming from the mandatory structural power of the organization, however, makes up for the lack of performance legitimacy, ensuring that enough organizational resources are put into technology application. Despite the uncertainty, a technology's functionality starts its adoption and accelerates the process later. When the consensus within an organization is that the performance potential of a technology has not yet been met, a technology may be removed as an organizational task, causing a crisis in its adoption. Value legitimacy from professionals and their allies, in the form of informal resources that continue to support the existence of technology within the organization, waits for potential survival opportunities. A comparison of the three dimensions of legitimacy is listed in Table 1, including their assessment criteria, their power sources, their action points, their mechanisms of action, their effects, and so on.

The differences between the intra-organizational legitimacy dimensions here and those in the previous studies include the following: (1) I link the legitimacy concept with the specific organizational activity and the new technology adoption, emphasizing the practical attributes of technology in adopting organizations but not their abstract and general characters, highlighting the context-dependent practical features of the technology and (2) I highlight the value-oriented logic of the actions of the organizational actors' by revealing how the value evaluation of technology by the organizational members affect technology adoption.

In summary, the key factor at the organizational level facilitating or hindering new technology application is whether or not it obtains sufficient organizational legitimacy. Furthermore, organizational legitimacy is made up of performance legitimacy, task legitimacy, and value legitimacy. Later, I will use this framework to analyze the application of ERP in Da Company to show how the legitimacy of this technology is closely related to its periodic application outcomes. 
Table 1 Comparison of the three dimensions of the intra-organizational legitimacy of technology

\begin{tabular}{|c|c|c|c|c|c|c|}
\hline Dimension & Assessor & Criteria & $\begin{array}{l}\text { Power } \\
\text { resource }\end{array}$ & Spot of action & Mechanism & The role \\
\hline \multirow[t]{2}{*}{$\begin{array}{l}\text { Performance } \\
\text { legitimacy }\end{array}$} & $\begin{array}{l}\text { Other users on } \\
\text { the market }\end{array}$ & $\begin{array}{l}\text { Technical } \\
\text { maturity, } \\
\text { market } \\
\text { ranking, cases } \\
\text { of influential } \\
\text { and successful } \\
\text { adoption, etc. }\end{array}$ & $\begin{array}{l}\text { Based on } \\
\text { external } \\
\text { performance } \\
\text { recognition }\end{array}$ & $\begin{array}{l}\text { When decide } \\
\text { whether or } \\
\text { not to adopt } \\
\text { the } \\
\text { technology }\end{array}$ & $\begin{array}{l}\text { Affecting the } \\
\text { technology } \\
\text { adoption } \\
\text { decision }\end{array}$ & $\begin{array}{l}\text { Important } \\
\text { reference } \\
\text { for the } \\
\text { adoption } \\
\text { decision }\end{array}$ \\
\hline & $\begin{array}{l}\text { Organizational } \\
\text { members }^{\mathrm{a}}\end{array}$ & $\begin{array}{l}\text { Technology- } \\
\text { organization } \\
\text { fit, cost- } \\
\text { benefit ratio } \\
\text { calculation in } \\
\text { technology } \\
\text { adoption }\end{array}$ & $\begin{array}{l}\text { Based on } \\
\text { internal } \\
\text { performance } \\
\text { recognition }\end{array}$ & $\begin{array}{l}\text { Organizational } \\
\text { members' will } \\
\text { to meet the } \\
\text { change } \\
\text { requirements } \\
\text { for the } \\
\text { technology } \\
\text { use }\end{array}$ & $\begin{array}{l}\text { Affecting } \\
\text { organizational } \\
\text { members' } \\
\text { tolerance to } \\
\text { the application } \\
\text { challenges, like } \\
\text { resource- } \\
\text { demands, } \\
\text { change re- } \\
\text { quirements, } \\
\text { amounts of } \\
\text { problems, etc. }\end{array}$ & $\begin{array}{l}\text { The basis } \\
\text { on which } \\
\text { the } \\
\text { technology } \\
\text { is used }\end{array}$ \\
\hline $\begin{array}{l}\text { Task } \\
\text { legitimacy }\end{array}$ & $\begin{array}{l}\text { Organizational } \\
\text { leaders and } \\
\text { multi-level } \\
\text { managers }\end{array}$ & $\begin{array}{l}\text { Compulsory } \\
\text { strength of } \\
\text { task of the } \\
\text { technology } \\
\text { adoption }\end{array}$ & $\begin{array}{l}\text { Based on the } \\
\text { recognition of } \\
\text { organizational } \\
\text { authorities }\end{array}$ & $\begin{array}{l}\text { Amount of } \\
\text { formal } \\
\text { resources } \\
\text { input into the } \\
\text { technology } \\
\text { application }\end{array}$ & $\begin{array}{l}\text { Decide the } \\
\text { amount of } \\
\text { formal } \\
\text { organizational } \\
\text { resources } \\
\text { input, the } \\
\text { organizational } \\
\text { members' will } \\
\text { to adapt to the } \\
\text { technology, } \\
\text { the room left } \\
\text { for the } \\
\text { opponents to } \\
\text { negotiate }\end{array}$ & $\begin{array}{l}\text { To } \\
\text { guarantee } \\
\text { the success } \\
\text { of } \\
\text { technology } \\
\text { adoption }\end{array}$ \\
\hline $\begin{array}{l}\text { Value } \\
\text { legitimacy }\end{array}$ & $\begin{array}{l}\text { Organizational } \\
\text { members }\end{array}$ & $\begin{array}{l}\text { Implication of } \\
\text { the } \\
\text { technology for } \\
\text { long-term } \\
\text { organizational } \\
\text { development }\end{array}$ & $\begin{array}{l}\text { Based on the } \\
\text { recognition of } \\
\text { the } \\
\text { technology } \\
\text { acting on the } \\
\text { organizational } \\
\text { future }\end{array}$ & $\begin{array}{l}\text { Drive the } \\
\text { informal } \\
\text { resources } \\
\text { input for } \\
\text { technology } \\
\text { application }\end{array}$ & $\begin{array}{l}\text { Initiate the } \\
\text { organizational } \\
\text { members to } \\
\text { cooperate with } \\
\text { technology } \\
\text { adoption. } \\
\text { When formal } \\
\text { resources lack, } \\
\text { it activates the } \\
\text { informal } \\
\text { resources input } \\
\text { to maintain the } \\
\text { technology's } \\
\text { survival; when } \\
\text { task legitimacy } \\
\text { and } \\
\text { performance } \\
\text { legitimacy are } \\
\text { given, it } \\
\text { facilitates } \\
\text { technology } \\
\text { application. }\end{array}$ & $\begin{array}{l}\text { To help the } \\
\text { technology } \\
\text { to survive } \\
\text { during } \\
\text { crises and } \\
\text { promote its } \\
\text { application } \\
\text { when used }\end{array}$ \\
\hline
\end{tabular}

ancluding the decision-makers

\section{The process of ERP as applied in Da Company: from "dead" to "alive"}

Da Company is a Chinese state-owned company composed of a number of functional departments, such as management, finance, and procurement. They shall be collectively referred to as the platform departments, of which they perform services, staff management, and supervision duties, and they are all subordinate branches/subsidiaries. ERP 
intended to digitize the entire company's production and management processes to optimize management. It was applied in the various platform departments and all the subsidiary and branch companies. The company produces civilian and military products, and it is famous for having been the biggest domestic supplier of television sets.

In June 1998, the company tried to purchase all color picture tubes, the very core component for TV sets, on the domestic market, for it had planned to monopolize television production and supply in China. But because its inventory data was not clear, the products could not be set at reasonably competitive, low prices for promotion, which was considered the best effective promotion strategy by the market at the time. As a result, the company's market share declined. It was clear that the company's deeply opaque information was its bottleneck in an attempt to fulfill this market solution, hindering the company's strategy implementation and causing the company's losses. In December, the company set up an Informatization Management Office (IMO), and Old Yin was designated as the group leader to make the informatization plan. In April 1999, Ji, the board chairman, and general manager decided to introduce the ERP system at Old Yin's suggestion. In August, Da signed an ERP purchase contract with SAP, the biggest ERP supplier worldwide. In October, the ERP project was scheduled to start, and they called a launch in May 2000 with four modules: Financial (FI), Sales and Distribution (SD), Material Management (MM), and Plant Maintenance (PM). Meanwhile, the consequences of the malicious monopoly strategy in 1998 were completely uncovered. Their profits slipped from 3.15 billion yuan in 1998 to 1.57 billion yuan in 1999, and their profit output in the second half of 1999 was less than 100 million yuan. In May 2000, Ji left the company citing illness, and Yao was appointed as the temporary general manager. In July, 2 months later than expected, Yao officially "pressed the button in person" to "launch" ERP's application. Old Yin was responsible for project execution.

By January 2001, the company had been operating without performance improvements. This was when Ji returned to the company and regained power, then Yao left. Informatization was the solution to the long-standing management problems, and implementing the plan set by Ji before he left was now his focus as he returned to the company. In March, Ji promoted Old Yin from Informatization Director to Senior Manager of the Integrated Management Department. However, almost every user department complained about the mismatch between ERP and the specific management process, saying that ERP was too manpower-demanding and the unreasonable new business process greatly hindered marketing activities. Ji then doubted ERP and in May redacted Yin's promotion. "I was demoted from a high managerial position all the way down to a common mass employee" (Old Yin 0809). In June, Old Yin was re-appointed as the director of IMO, returning to his old position. Meanwhile, the company held a meeting for middle management and above. The managers of most of the departments accused the informatization team of excessive human resources use and inefficiency. The cancelation of ERP was proposed, and Old Yin shed tears at the meeting. ${ }^{2}$ From then, ERP's application entered a three-year period of stagnation. That is, the next-step

${ }^{2}$ Old Yin is an iconic person of the informatization process in Da Company. His up and down in career after ERP adoption served as a symbol that signified the key time points of the ups and downs of ERP's adoption. That Old Yin publicly shed tears because of frustrations in ERP's application was considered as a profound story in the company's informatization history. Most respondents in my survey referred to this event, which indicated the difficulties and twists of ERP's adoption in Da Company. 
application plan of ERP was shelved, and the existing financial, sales and purchasing modules were barely maintained at the cost of destructive modification. The data in the ERP system could not be used, and it did not meet data quality standards. The loss of technical staff continued, and the IMO was constantly challenged and questioned. In 2002, the ERP project operations of Da Company caused public concern, and there were rumors that Da had failed in its adoption of ERP. Investigative reports on why and how were issued in the media. But Da Company denied failure.

In July 2004, Ji retired and Yao came back again and assumed the highest command. A few days later, Yao promoted Old Yin as the vice director of the Integrated Management Department, and he announced, "From now on, it is not permitted to discuss how many problems ERP has. Employees may only discuss how to solve these problems. If anyone is in ERP's way, he's in my way." Since then, the ERP project jumped into a stage of rapid development. By December, the largest module, the sales module, had been applied to 203 sales branches throughout the country within 4 months. Then, during the following company restructuring, the IMO was incorporated into the most powerful department at the time, the Management and Supervision Department, and Old Yin served as the vice director and was in charge of informatization as well.

In 2005, Old Yin retired, and his long-time follower Gui took over the post of vice director of the department. He was then promoted to be the director. In the same period, the information technology team expanded rapidly, and the outflow of technicians began to return. At the end of the year, the information team was awarded the "President's Special Award." In 2006, informatization entered a period of full promotion, and the information demand of the whole company was in blowout. In March 2008, Da company established Xinyi Software Company, trying to integrate the internal experience to provide enterprise information services for outside customers.

As shown in Fig. 1, each number represents a key point in time, combining the text in the diagram box to mark the ERP adoption process in the company: the introduction, the launch, the stagnation, the restart, the deep application, and the establishment of a company by the information technology team to provide ERP service to the external market. The arrow in the diagram represents the time axis. The horizontal line represents a basic qualification as an organizational task, indicating the necessity of specific organizational projects to the organization, which determined whether the organization invested resources in it or not. The two vertical dotted lines are used to indicate the relative position of the ERP application in the entire organization task system/ranking. Placement above the horizontal line indicates having more importance than normal organizational tasks; placement below indicates less importance. The fluctuating line is drawn according to the relative position of ERP in the organization's task system at each time node, giving indications throughout the course of its 9-year adoption how ERP underwent changes in the degree of its importance to the organization.

\section{Changes in multiple forms of intra-organizational legitimacy of the technology, and the ups and downs in its adoption} Introduction: strong external performance legitimacy led to the technology's introduction How did the new technology get into the company? Technology introduction comes at a cost, and a company must first consider its returns. Indices of its technical 


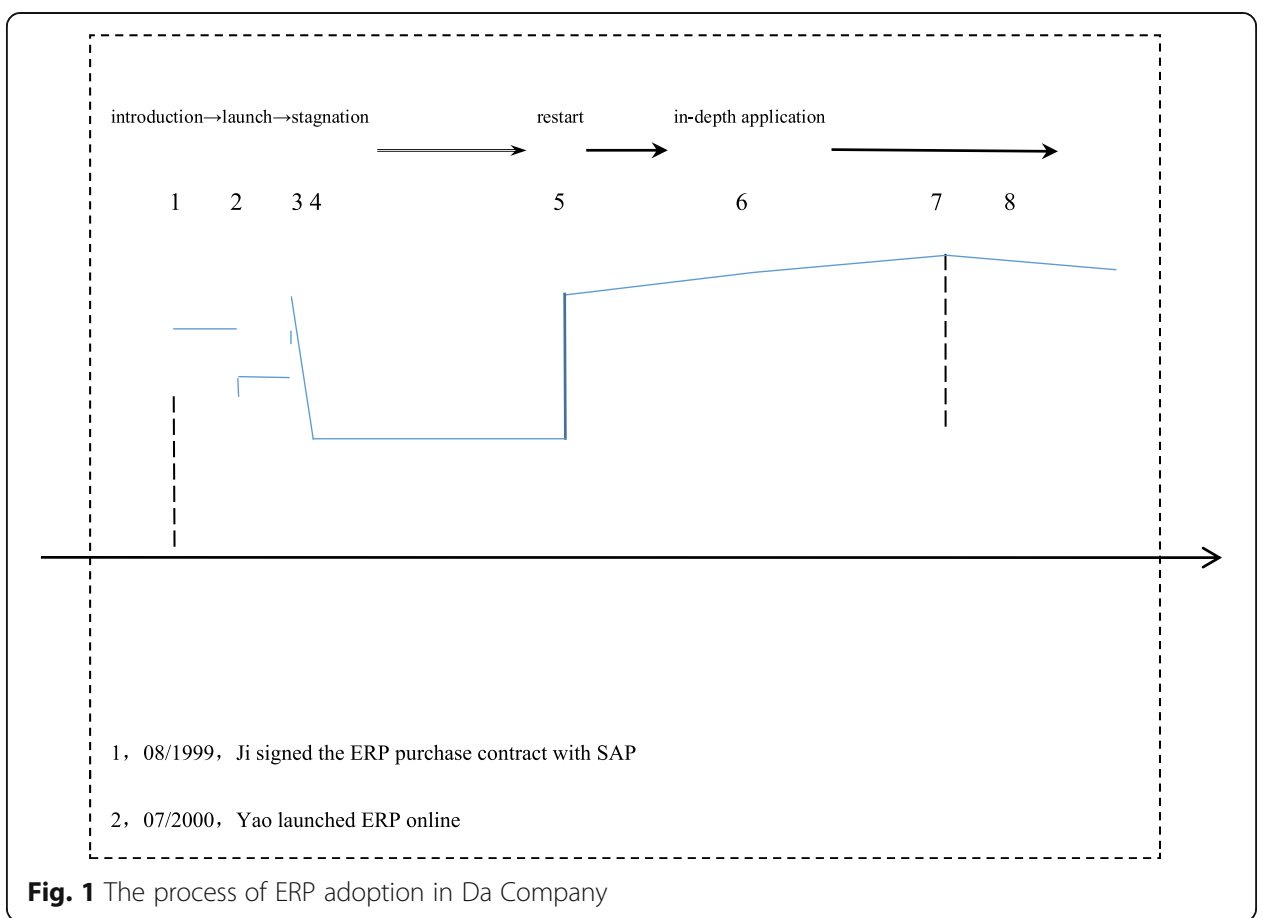

performance potential, such as the technology's rank in the industry, its market share and the reputation of the supplier are crucial as company decision-making references. Before an enterprise introduces a technology, technology selection should be carried out. Da Company took a long time to compare and decide upon its ERP supplier. At the beginning of 1999, there were eight manufacturers in product selection, three of which were outstanding and remained after the first round of filtering: Oracle, BaaN, and SAP. Oracle had already cooperated with the company before, and their price was quite attractive. In addition, the finance department tended towards Oracle, as ERP systems typically consider the financial model their core. But BaaN ERP could be technically more customizable in modeling, so process restructuring with the organization would be more convenient, and process reorganization is considered a key and important point of ERP adoption. SAP was the world's largest ERP supplier. At that time, the ERP market in China had just arisen, and all of the suppliers lacked success stories, which increased the difficulty for the company to make a decision. Finally, it came down to SAP's comprehensive ranking in the industry. Its largest and first-place ranking was a strong signal of comfort, easing the adopter's sense of uncertainty in their decision and subjectively helping to satisfy the need for risk-avoidance.

During introduction, ERP had a high degree of task legitimacy in the company, because it was introduced by Ji, the authoritarian decision-maker, as he designated himself as the leader of the project executive team.

The value legitimacy of ERP in this stage was generally not high, coming mainly from Old Yin. He was always a staunch supporter of ERP. An organizational story said that in April 1999, after listening to the 9-h report from Old Yin's team, Ji decided on ERP adoption immediately. Old Yin's confidence in ERP application and enterprise informatization was derived from his observation and consideration of ERP for years. In 1992, he went to Germany on a business trip to a supplier company that used ERP and saw how great ERP was in promoting efficient management. After returning to China, he 
developed an inventory management system for the company, close to the MRP prototype. By the end of 1998, the capital turnover rate of the purchasing department of the company had been cut down from 128 to 21 days. In 1995, he studied MRP for the company and began to investigate ERP in 1997. In contrast, Ji's expectations for ERP were not because of his understanding of the technology, so actually his attitude was not firm, which led later to his changing decisions on ERP. "The big boss was skeptical. He just felt the need for something to improve management efficiency, but he was not sure whether that thing was ERP or not... and this turned out to be a problem later" (Old Yin 0809).

In short, with the support of external performance legitimacy, ERP was introduced into the company, and the organizational decisions coming from the authoritarian big boss endowed it with great task legitimacy. ERP had no value legitimacy, however, from the supreme leader, partly deriving from his ignorance of ERP, which indicated the possibility that when the technology's adoption would later encounter difficulties, the attitude of the big boss would turn from support to doubt.

\section{Launch/implementation: the same task but different task legitimacy intensities}

The company originally planned to launch the ERP project in May 2000, but afterwards, due to the superior authority of the SASAC (the State-owned Assets Supervision and Administration Commission) which was against the "uncertain prospects" of the project, Ji suspended ERP. "At that time in China very few companies adopted ERP, and no one could beat his chest in guarantee (of its effects)" (Gui 0808). In July, Ji was too ill to preside over the company, so Yao took over instead. Unlike Ji, Yao always had a firm desire for informatization work and considered it in line with the strategic development of the enterprise. With a firmly supportive attitude, he decided to "withstand the pressure to launch ERP" (Old Yin 0809). During his 8-month tenure in office, the staff of the Department of Information Management doubled. During launch, the task legitimacy of ERP was prominent, and this strength directly led to the commencement of ERP's use. Comparing Ji and Yao, both were the company's top decision-makers, both were ERP implementation team leaders in favor of adopting ERP, and both encountered objections from superiors, but Ji "suspended" the ERP project while Yao "withstood the pressure" to start it.

Organizational research often associates business decisions with the personal traits of business leaders, such as in entrepreneurship. But in this case, the personal characteristics of the two executives could not explain the behavior differences between the two in the decision-making surrounding the start of ERP use. Ji, in charge of Da Company since 1985 and known as the "iron hand," had great achievements leading the company to increase its net assets over 300 fold, giving the company the leading role in the household electrical appliance manufacturing industry, so he was honored as the organizational "hero" and even the "father" of the company. Employees described him as "dictatorial" and "hard," having absolute power over the company. Comparatively, Yao was "moderate," "gentle," and only 36 years old when he took over the company in 2001. But decisive and courageous Ji did not insist on his previous decisions on ERP adoption, while the young and gentle Yao started ERP against the same great pressure, even at the beginning of his tenure. Negative comments from superior authorities were 
undoubtedly important. It is this crisis of technology adoption that forced exposure of the inner understanding and value-belief differences regarding ERP between the two leaders. It can be seen that when faced with a dilemma, formal organizational decisions from the same organizational power level reveal their inner substantive differences, and only decisions with substantive belief, partly based on the knowledge of ERP, can provide resources for technology to survive future difficulties. Though some research has found a lack of knowledge regarding ERP may have led to the failure of ERP implementation (Rajapakse and Seddon 2005), I would like to say that different understandings and beliefs may have led to different implementations of the same decision to adopt ERP.

\section{Stagnation: value legitimacy supported ERP through its crisis}

Eight months after the launch of ERP, its intra-organizational performance legitimacy had not generally been established yet. In March 2001, Ji returned to control the company again. During the same month, he adjusted the organizational structure, the IMO was merged into the Comprehensive Management and Supervision Department (CMSD), and Old Yin was promoted to be the chief manager of the Department from having been the director of the Office, which was considered a supportive signal to propel ERP adoption. But Ji later kept hearing complaints from his managers whose departments were involved with the four modules of ERP adoption, except for the Financial Department. Take the Sales Department, for example. Because the ERP system did not match with their existing database, the system was slow to respond, and the list-printing load was large, data entry was less timely and not synchronized. This caused an inability to print invoices to merchants on time to deduct their input taxes, subsequently affecting sales. This consequence was undoubtedly very serious in their organizational culture in which sales had undoubtedly been a priority at the time.

The IMO believed, however, that the key to sales performance was in product innovation and market competition, but not sales and promotions, and the short-term inconvenience caused by ERP adoption then was just a "convenient scapegoat" for their wrong market strategy. The truth might be that due to ERP's application, the data were timely and transparent, squeezing out room to cheat on part of the sales staff and thus triggering their boycott. As in the previous analysis, due to the lack of confidence in ERP and the great value placed on sales, Ji believed the Sales Department manager's assertion and used the excuse of readjusting organizational structure to dismiss Old Yin from the chief position of CMSD, "all the way down to the bottom, without any title" (Old Yin 0809). The IMO again was demoted to a secondary unit. Then a document was issued, ranking the IMO as the "ninth" secondary unit, which had the profound implication of being despised and repelled in Chinese culture since the Great Cultural Revolution. Old Yin's dramatic promotion and demotion "caused the followers to be at a great loss" (Jiali 0809). In June, the company held a meeting for middle management and above, and the Sales Department and Purchasing Department openly and strongly accused the ERP operation. Old Yin shed tears at the venue, which later was considered as a landmark event in the company's course of ERP adoption, marking the start of the stagnation phase. The task legitimacy of ERP plummeted and staff in the IMO left, resulting in the shrinking of the team from 12 professionals to 3 in a very short time. 
ERP was suspended for 3 years. A few modules were barely maintained and destructively modified. According to information technology professionals, the action logic should have been to optimize the production and management process according to the best industrial practices embedded in ERP. But, in fact, all departments were demanding the system modules to be modified to fit the old processes and work habits. The professionals in IMO had to "cater" to customer departments to do even destructive modifications to ERP modules in order to maintain ERP at the minimum level- "it seems like someone was still using it." At that time, the external performance of ERP was equally at risk. At this point, the prevalent description of the ERP adoption dilemma in the Chinese ERP market was, "If you're not using ERP, you're waiting to die. If you're using it, you're asking to die." The adoption success rate of ERP reported by various media outlets was only $20-30 \%$. Why was ERP not cleared out from Da Company, however, just like the fate of other projects destined to fail?

The survival of ERP depended mainly on the resources invested by Old Yin and his team informally, or even personally. Subjectively, Old Yin always had a rational understanding and firm belief in ERP. He believed that "It was a big risk to implement ERP, but it was essentially important for the future development of the company. Therefore, we had to use it as soon as possible" (Old Yin 0809). Objectively speaking, his longstanding professional and loyal reputation in the company and his network provided the minimum resources for ERP maintenance at the lowest level in the company. Yin entered the factory in 1964, worked step by step from the bottom to the middle then upper management and was one of the organizational "heroes." After he shed tears at the management meeting, the staff of the IMO were drained out and headhunters also tried to persuade him to switch jobs. But he was determined to stay and tried his best to help retain ERP. The resources that Old Yin made full use of his own network to find included looking for the funds necessary for the operation of ERP. At that time, a vice president "secretly" gave Old Yin capital support, "I found top-ups from Vice president Lan ... I begged him... He sometimes granted me tens of thousands of dollars to do the things that I had to do to save ERP" (Old Yin 0809). Other resources included the professional technology needed for system adaptation. The loss of professional staff meant that the system's leftover problems were unsolvable, so Old Yin "cheekily" called those who had job-hopped to other companies "for their own personal growth"; it was these "Foreign Corps" that helped to supply necessary technological support for ERP's adaptation.

"Any achievement requires sacrifice and extraordinary effort, or else success is impossible. ... And I would like to fight for this cause, as informatization started from ERP and got it going. In this company, ERP is not easy to use. In those days it was like we were just doing something very miserable. Our faces looked very bad ... During that time, the main role I played was for the professional team. I always stood by them, taking responsibility, holding the door. It was me there to bear the leader's burden and the accusations from other high-ranking managers. But below that ... my team needed to suffer user complaints and obstruction. They came back to report to me. If they asked me for a favor, I would go and beg for others' support of our work. I checked ... when the information technology was denied by the board, if there was no longer a team in the company willing to fight for it, then no doubt failure would come ... [Because] how could you do this without any resources?" (Old Yin 0809) 
Since the big boss Ji had definitely claimed to no longer support the use of ERP, why were the modules still there running at a minimum level? This was because of the informal resource input driven by the value legitimacy of ERP. The value legitimacy of technology embodies an awareness in the organizational members on the significance of the technology to the organization, and this knowledge can be passed through interpersonal trust, helping to form a company-wide, loose league of value. Vice President Lan's secret support for the informatization work was based on his trust in Old Yin, his professional judgment and his loyalty to the company. Another reason is that "ERP was launched by Yao in person. He was the deputy mayor in the city and the first post-doctoral general manager in China then. If he was so supportive to this system, people think, then it might be not so wrong. So even though the situation was very challenging, nobody dared to propose stopping and excluding it completely. Who could predict the future? Normal people made references to able persons. It was also the influence of Yao's insistence that helped ERP to hang in there" (Old Yin 0809).

Regarding performance legitimacy, ERP also encountered some self-certification opportunities. First, external successful cases of ERP adoption appeared, such as at Lenovo Company. Later, a large number of reports that emerged on the domestic ERP market played a very good, nurturing role. Second, in 2003, the USA, exclusively relying on ERP for data collection in the anti-dumping investigation of Da Company, demonstrated to the organization the international, high professional reputation of ERP from SAP. "The Americans said that they could only believe the ERP data... nothing else, so although my (ERP) system was not well run, it couldn't be easily cut out" (Old Yin 0809). Regarding internal performance legitimacy, the differentiation of performance legitimacy among user departments also provided some room for the survival of ERP. Among the four modules put into use, the financial module application was relatively good. Although the Finance Department also questioned ERP in June 2001 at the managers' meeting, the department insisted on trying to make good use of ERP during the following period of stagnation. They made assumptions about the value of technology differently, "We have the assumption that you eventually need informatization. That the advantages of ERP were not played out does not mean that ERP was the wrong solution, but rather that we may have been using it in the wrong way, though the other departments do not think so. They doubt if it is the right solution" (Dalin 0808) ${ }^{3}$ This showed how the value legitimacy of ERP in the Finance Department worked.

In short, during its 3 years of stagnation, ERP existed in the organization without task legitimacy and basically without any internal performance legitimacy, mainly due to the differentiation of its value legitimacy among the members of the organization, Old Yin's team and their value alliance supplying the minimum of informal and even personal resources to help ERP to survive. At the same time, the increase of legitimacy of external performance put uncertainty on the internal performance legitimacy judgment; with the doubtful but not definite denial of ERP, the technology could not be completely excluded, even with no more formal resource inputs.

\section{Restart: task legitimacy was strengthened}

After the stagnation period, ERP was restarted by its rocketing task legitimacy.

${ }^{3}$ Dalin was the Chief Financial Officer of the Company. 
In July 2004, Yao took Ji's place to run Da Company. The first thing he decided was to restart ERP, clearly and openly showing his strong will on ERP. "Whoever gets in the way of ERP, gets in my way" (Guiren 0808). Subsequently, Yao continued to strengthen the task legitimacy of ERP. First, he clearly and publicly declared his strong supportive attitude. Second, he started the organizational restructuring process of merging the IMO into the No. 1 management department, and he promoted the director of the IMO to be the chief of the department. Third, most departments were required to cut staff, but the informatization technician team were given the right to expand. Fourth, at the end of 2005, the technician team was awarded "the Chairman's Special Award," and it gradually expanded from 4 in 2004 to more than 20 in 2005. ERP adoption as an organizational task were given the highest prioritization, and the whole company changed its attitude towards ERP, going from the previous stance of "blaming each other when there was a problem" to "working together to find a solution if there is a problem" (Dawn 0808). ${ }^{4}$

This process also saw the external performance legitimacy of ERP increase. ERP vendors poured into the market, successful cases of adoption were seen more frequently, and society-wide discussions on enterprise informatization cultivated an understanding of ERP. In terms of internal performance legitimacy, there were two things that changed people's perceptions and attitudes. First, the technician team managed to apply the sales order management module to 203 sales subsidiaries across the country within 4 months. Once the system was running normally, the company was able to obtain timely sales data for all branches throughout the country, so the technological and management problems that the Sales Department had complained about before were solved. Second, in 2005, the informatization team launched an online procurement bidding system. When the price of raw materials doubled on the market, online bidding made the purchase price of raw materials fall by $19 \%$, and the highest drop rate of subsequent tenders was more than 40\%. "In two hours it helped to save more than 3 million for the company, and someone even joked that it seemed like printing money ... It was very convincing and impressive" (Guiren 0808).

Regarding value legitimacy, training lectures given by top leaders and managers at all levels in the organization made employees realize that making good use of ERP was of great significance to the development and future of the company. This was an inevitable trend. This understanding spread from the president Yao and Old Yin, who was in charge of the most powerful department, then down through various levels of employment in Da Company and out to the branches. Jian was also a "veteran" of the company like Old Yin. In 2001, he was the sales director of the company. At the managers meeting in June, his opposition to ERP was the fiercest. But by 2005, he summed up his cognitive shift, saying "My understanding of informatization, including ERP's adoption, has shifted from not understanding to understanding, to support, and now to firm support" (Jian 0808).

\footnotetext{
${ }^{4}$ During the ERP stagnation period, Dawn was the one who actively requested to transfer to the Informatization Management Office from the Procurement Department, which was considered much more rewarding. He was a firm advocate of informatization, and his active "downgrade" in position was the result of a combination his knowledge of the role of information technology on the future of the company and his personal future-oriented career development plan. He had been grown into an important technical backbone and the top management of the company.
} 
In short, from the ERP reboot until the end of 2005, Yao always kept strengthening the task legitimacy of ERP, such as through his promotion of who originally was in charge of informatization work to the head of the first power sector, and the informatization technician team expanded fivefold. The development of the external market of ERP helped to increase its external performance legitimacy, and its internal performance legitimacy grew as the sales module showed its ability to improve performance after it was thoroughly used. The value legitimacy of ERP proliferated within the organization, and with the help of the internal training system it trickled down through all levels of employment.

\section{In-depth application: the establishment of internal performance legitimacy}

By 2006, technological performance was demonstrated, and the internal performance validity of ERP had been finally established within 6 years. For example, in the procurement department, under the same conditions the procurement cycle shortened from 25 to 30 days to 2 days at the shortest, and the occupation of inventory funds dropped from 15 to 17 billion to 2-3 billion; capital turnover decreased from the original 18 days to 10 days. The Finance Department had continued substituting routine work, like accounting jobs, with the system, so the number of staff kept shrinking while the company grew in size. Take one subordinate of the Multimedia Company as an example, where more than 100 billion in sales only needed 20 financial staff: "Other companies in the same industry and of the same size but without ERP have financial staff numbering more than 110 people" (Jiajia 0808).

Technology continued to be used in-depth, which reflected the company's informatization planning. In 2006, ERP, as the company's base information technology platform, was completely built, and all departments surrounded the data platform to develop other information technology projects, which made the informatization work within the organization deepen to a stage of platform integration. In 2007, the company's informatization work focused on integrating ERP with branch projects and diffused it to its global subsidiaries. In 2008, the ERP system started to extend outside to the upstream and downstream of the business line, trying to build an integrated value chain across company boundaries, such as by networking with banks and customs, realizing data exchange with suppliers, etc. Meanwhile, the rapid expansion of the staff of the IMO and the continued return of former employees who left while ERP was stagnating added up to over 80 people by the beginning of 2008 and 120 by the end of the year.

The performance legitimacy of ERP further stimulated task legitimacy to permeate from the board of directors to the Department of Management and Supervision, which was the most powerful department and which was in charge of the informatization work at other user departments and proliferation to every branch/subsidiary. When performance legitimacy and task legitimacy were given, value legitimacy once again demonstrated itself as a deep-rooted dynamic to propel technology use. It meant that even within the same company, under the condition of controlling the technical difficulty of different modules, various departments might use ERP modules at greatly different paces, resulting in varying technological performance.

To make this clear, let us examine the application of FI and PPCO (two modules in ERP) in the Multimedia Company, one branch of Da Corporation. Multimedia 
Company began using ERP in late 2005. Jiaxun from the Group Finance Department was designated as the director of the Finance Department in Multimedia. He brought a welcoming attitude towards informatization work into practice by "facing all problems and thinking about how to use information technology to solve them in lieu of other solutions. Let this be the automatic response in our minds." He also "started a revolution against ourselves in the informatization era" (Jiaxun 0808), saying that "our biggest goal is to optimize the business with information technology and thus fire ourselves" (Shaohang 0809). By 2006, to create a shared service center, accounting services were performed by information technology, the staff relocated their work to data analysis and mining, such as business plan monitoring, budget execution supervision, cost reduction analysis, external customer credit management, and risk control. The Finance Department deeply "intervened" in its business to improve it.

Meanwhile, the adoption of the PPCO Modules (Production Planning and Cost) in Multimedia Company experienced a different situation. Easy to understand, the company was mainly engaged in the production of home appliances, and the PPCO module was thus extremely important to the company. Unlike the active attitude in the finance department, however, PPCO was used passively. When the project manager Chao found that some departments did not cooperate in the necessary investigation during the first step, he asked the general manager Xu to endow task legitimacy to ERP. Xu then declared, "whoever gets in ERP's way, gets in my way." But he also said that "after all, the administrative order does not help user understanding, as they just behave a little bit more cooperatively under pressure." Chao said, "I cannot actually ask Xu to fire anyone because he's not cooperating with ERP's application." But what he could do to manage this resistance was to apply gentler and wiser strategies, like "more rewards, less punishments," "more encouragement, less criticism," and "killing a chicken in front of a monkey" to help advance the project. He proposed his solution to the situation: "First, perform ERP stiffly without understanding, then understand and perform it voluntarily, and finally understand and optimize it innitiatively," which was quite different from the situation in the Financial Department. The company took extra time otherwise not necessary to use PPCO modules, comparing it to its FI module adoption under the condition of "controlling the technical complexity differences between the modules," even though, "in fact, the PPCO module company is more essential for the business than the FI module" (Chao 0809).

To summarize ERP's application at this stage, its performance legitimacy had been established and its task legitimacy had continued to permeate from the top to the bottom, from the corporation to its branches. While the two forms of legitimacy were steady, value legitimacy showed its independent influence on the promotion of the technology's adoption.

\section{The effect of technology application and the covariance of technology legitimacy}

Above, I demonstrated in detail the changes of intra-organizational legitimacy of ERP, including its performance legitimacy, task legitimacy, and value legitimacy. I also demonstrated the reasons for the changes as well as the technology application results affected by the changes. We saw that the overall intra-organizational legitimacy of ERP at every stage of its adoption played a significant role, and in each stage there was one 
specific legitimacy that played a leading role. But how does the success or failure of technology correspond to its organizational legitimacy? First, how we define the success of technology adoption/application should be discussed.

This is a complicated issue. First, the definition of success or failure is usually based on indices for technical effect or user satisfaction assessments. In other words, either objective perspectives or subjective perspectives are used. Second, when evaluating the effect of technology application, people also argue about whether it is focused on procedural indicators or outcome indicators. For example, when the whole industry defined Da's failure to implement ERP in 2002, Old Yin did not admit defeat; he argued that "there is still an amount of data running in the ERP system every day," and "the technology is still used by people in the company" (Old Yin 0207). But Ji thought that obviously ERP could not be defined as a success, because the data in ERP could not be used for organizational decisions as it promised. Third, if the evaluation adopted the indices for user satisfaction, there would be the question of whose satisfaction counts, because different users have different understandings of and expectations for technology adoption, which would affect the evaluations. For example, in 2005, before and after the production planning (PP) and controlling $(\mathrm{CO})$ modules were used, the variance rate in cost accounting prediction dramatically dropped from 20 to $0.3 \%$. Both the IMO and the Production Management Department felt that this was excellent, while the board president Yao did not think so because his expected target was $0.1 \%$. Therefore, if the success or failure of a technology adoption is understood as a gradually evolving process of performance, then success or failure cannot be represented by a critical point-a specific value index-but rather is represented by a continuous spectrum. This paper applies the objective assessment method to score the application outcomes at all stages of ERP adoption. The evaluation instrument is the $A B C D$ Evaluation Table ${ }^{5}$ the internationally used ERP Application Performance Indices from Oliver Wight company.

To summarize the changes in the intra-organization legitimacy of ERP in various stages of application and the effect of the technology adoption, we get the corresponding covariant relationship between them, as shown in Table 2.

As shown in the table, with the ERP introduction decision as a starting point, in the project launch phase, the increase of the legitimacy at Launch Point 2 (July 2000) is compared to that at Launch Point 1 (May 2000). Under pressure from the higher

\footnotetext{
${ }^{5}$ The Evaluation Form for ERP was first proposed by Oliver Wight in 1977. It has 20 questions and can be divided into three sections: technology, data accuracy, and system usage. In the second edition, it was given a subgroup of questions concerning "Education and Training." Now, the second edition is most widely used. The company scores each indicator according to its own ERP application performance, from 0 to 4 , representing "no" (this activity must be done but is not currently done), "poor" (the people, processes, data, and systems have not yet met the lowest level of requirements, and if it brings profit, it is extremely low), "normal" (most processes and tools are ready for use but are not fully utilized or have not yet achieved the desired results), "good" (all work is completed as assumed and the designed goals has achieved), "excellent" (the best results wanted have been achieved). Summing up all the values, the result, that is the fulfillment or achievement level of ERP's application is obtained/signified. The ABCD has four levels: A, $\geq 3.5$ points, the planning and controlling business processes are effectively applied from the top management to the bottom personnel throughout the enterprise, and the business process is significantly improved, including enterprise customer service, productivity, inventory, cost, etc. B, 2.5-3.49 points, the new business process is supported by high-level management and is accepted and used by middle-level employment, and the company has gained obvious progress by applying ERP. C, 1.5-2.49 points, the process is mainly used as a materials procurement tool, which greatly promotes inventory management. D, $\leq 1.5$ points, the data accuracy of the business process in ERP is poor, and it has little help for actual business management improvement.
} 
Table 2 Covariant relationship between the intra-organizational legitimacy of ERP and its application effect

\begin{tabular}{|c|c|c|c|c|c|}
\hline Application phases & $\begin{array}{l}\text { Performance } \\
\text { legitimacy }\end{array}$ & $\begin{array}{l}\text { Task } \\
\text { legitimacy }\end{array}$ & $\begin{array}{l}\text { Value } \\
\text { legitimacy }\end{array}$ & $\begin{array}{l}\text { Intra-organizational } \\
\text { legitimacy }\end{array}$ & $\begin{array}{l}\text { The extent of success of the } \\
\text { ERP application }\end{array}$ \\
\hline \multicolumn{6}{|l|}{ Adoption decision } \\
\hline $\begin{array}{l}\text { Launch point } 1 \\
\text { (in plan) }\end{array}$ & & - & - & - & \\
\hline $\begin{array}{l}\text { Launch point } 2 \\
\text { (in practice) }\end{array}$ & & + & + & + & 1.5 \\
\hline Stagnation & - & - & - & - & $0.8^{\mathrm{a}}$ \\
\hline Reboot & + & + & + & + & 2.5 \\
\hline $\begin{array}{l}\text { In-depth } \\
\text { application }\end{array}$ & + & + & + & + & 3.8 \\
\hline
\end{tabular}

+ signs signify increased legitimacy compared to the last phase, - signs signify decreased legitimacy compared to the last phase ${ }^{a}$ The decline in the score ( 0.8 versus 1.5$)$ is due to the fact that ERP had been destructively changed to just the minimum qualification for existing in the organization-"at least someone is using it"

authority's disagreement with the new technology adoption, Ji changed his attitude towards ERP from support to hesitancy, which apparently reduced the task legitimacy of ERP and postponed the launch of the project. Comparatively, due to the value legitimacy of ERP in his mind, Yao chose to push the launch button, standing against the pressure from above once he assumed control. It is the enhancement of the task legitimacy from Ji to Yao that put ERP into use. After the technology was launched online in the company, due to internal differentiation of performance legitimacy among customer departments-the Sales Department and Purchasing Department certainly complained more than the Finance Department-in which ERP developed favorable as well as unfavorable strengths, there was almost no change in its hedging. In the stagnant phase, the legitimacy of all dimensions was reduced, the overall technology legitimacy shrank, and the effect of the technology's application became worse. During the reboot phase, the task legitimacy of ERP was enhanced suddenly and strongly. As a result, a large amount of resources was put into the technology's application, and its technical efficiency was gradually brought into play. Performance legitimacy was revealed and value legitimacy was also transmitted within the organization from top to bottom. The overall intra-organizational legitimacy of ERP rose, and the application effect of ERP jumped up, with the need for ERP and other information technology in the user department skyrocketing. During the wide-and-deep application stage, the legitimacy of all dimensions kept rising, and the organization benefited from the use of ERP and the whole work of informatization more and more. According to the scale assessment, ERP's application reached the "excellent" level ( $\geq 3.5$ points). Based on this case, we can safely say that the intra-organizational legitimacy of technology affects an organization's resource input for specific technology adoption, then affects the result of adopted technology, be it success or failure.

\section{Conclusion and discussion}

This study constructs an intra-organizational legitimacy framework to analyze a case of technology adoption/application, trying to uncover the conditional mechanism regarding how the intra-organizational legitimacy of technology affects its adoption results in organizations. This research shows that intra-organizational legitimacy of technology affects the amount of resources that an organization formally invests in the adoption, 
thus affecting its specific outcome and forming the distribution for the technology's successful application on a continuum between the two ends of complete failure and extreme success (if we express it figuratively). Therefore, the intra-organizational legitimacy of technology is essential for technology adoption in user organizations. Without a combined and sufficient intensity of performance legitimacy, task legitimacy, and value legitimacy, the technology in question has difficulty in obtaining enough user cooperation, making it impossible to be applied successfully. Basically, the introduction of new technology means changes to the degree of restructuring benefits distributions and changes to traditional work routines, and the logic behind employee actions is always a mixture of value (organizational commitment and professional ethics), organizational obligation, and self-interest.

Along the three dimensions of intra-organizational legitimacy of technology, performance legitimacy is the foundation, but the performance of a technology is always uncertain until adoption is completed. The role of task legitimacy lies in arbitrarily suspending performance and cost-benefit uncertainty and inputting organizational resources into the technology's application, which is the fundamental guarantee for its adoption. The decision-making behavior of the top decision-makers, however, is embedded in the decision-makers and performers, the general organizational structure as well as the specific organizational decision execution, which could cause changes to the decision later. If we use technology adoption as an example, the more uncertain the performance of the technology is, and the less confidence in the decision the decisionmakers will have and the more heavily they will depend on feedback later in subsequent execution processes to make possible decision adjustments. Thus, there will be more political room left for negotiation from practitioners at all levels. That is why, in this case, the generally decisive Ji was easily shaken by the upper authorities and then later persuaded by the Sales Department as well, backtracking on his own prior decision in this specific case of ERP adoption. The big boss' denial resulted in the loss of ERP task legitimacy, causing its stagnation.

At the same time, organizational staff are self-determined and value-oriented agents that do not react simply to administrative pressure nor are bound by job obligations. This implies that these actors invisibly but meaningfully increase or decrease the task legitimacy of technology in practice. As value-oriented actors, an organization's members' understanding of the value and significance of technology also plays an important role in technology application. When a technology encounters a task legitimacy crisis, value legitimacy can drive informal resources into technology adoption, supporting it to stay in the organization until a turning point is reached. When performance legitimacy and task legitimacy are certain, however, value legitimacy shows its dynamic role in promoting the substantial application of technology much deeper and wider than would otherwise be possible.

This study contributes theoretical insights in two aspects. Firstly, it does supplemental research in the IT-organization field. (1) It explains why a new technology can be used successfully under the uncertainty of internal and external environments from an organizational legitimacy perspective, revealing how the effect of technology application covaries with the fluctuation of its intra-organizational legitimacy. (2) It constructs a framework for the analysis of intra-organizational legitimacy of technology in three dimensions/forms: performance legitimacy, task legitimacy, and value legitimacy. The 
three dimensions are compared, which helps to open the black box of the technologyorganization interaction process from an organizational legitimacy perspective. (3) In this research, I consider employees as value actors instead of the self-interested purchasers or political players so very often seen in exiting literature. (4) This study also reveals how organizations possibly benefit from the gap between decision-makers and performers as an organizational correction mechanism, of which past IT-organization literature usually explored the harmful aspects it had on IT adoption.

Second, it supplements organization research. (1) Existing organizational legitimacy studies mostly focus on external legitimacy between organizations and their environment, while this study shifts to the insides of organizations, exploring intraorganizational legitimacy. (2) Unlike the various forms of legitimacy in existing literature, either in strategic traditions or in institutional traditions (Suchman 1995), the three forms in this research are constructed to explore the internal operation processes of an organization. They are more focused on concrete activities such as, specifically, the technology adoption of organizations in this case. (3) I also cross-evaluate the subjects (external observers or internal observers) and their assessments of objects (examining the organization's external activities or activities within the organization) to propose a classification framework for organizational legitimacy.

The practice of IT adoption can also be illuminated from this research. (1) For the practitioners of IT application, such as ERP execution consultants, I provide an analysis tool to help detect the legitimacy of a technology, locate the possible sources of resources, and find solutions. (2) It facilitates the broadening of horizons to go beyond the idea that only big bosses or top-level management can decide on technology adoption. The analysis shows that other than big bosses and top-level management, every employee, especially those who have good personal networks and are knowledgeable on the adopted technology, can spread technology legitimacy and mobilize the necessary resources for technology use. (3) Some scholars have pointed out that the lack of knowledge of ERP may have led to its failed implementation (Rajapakse and Seddon 2005), but the problem is that it is assumed that the knowledge of the whole organization is integrated and that all members have or have no knowledge of the technology. But actually, people are fragmented in this respect, as some are knowledgeable on the technology while others are not. (4) The internal activity on the technology's application is embedded in outside market performance and recognition, so it is better to proactively connect the inside key personnel with outside market development to help cultivate potential inside advocates.

What needs to be further discussed in the research is that the legitimacy of technology within an organization is affected by external factors. In this case, regarding task legitimacy, at the very start of adoption, the decision-maker's preference for ERP from SAP company was defined by its outside global high-tech supplier-market ranking; then during its adoption, when its industry market pressure increased sharply, in addition to the complaints of the Sales Department regarding ERP, the big boss made the decision to withdraw resources invested in the technology adoption and instead put them into marketing and sales. Regarding value legitimacy, how could the professionals hang in there so firmly when the big boss turned down ERP and they suffered much of the blame from user departments? This is because they, like Old Yin, had seen great, successful experiences in the outside world beyond China that helped them to better 
understand ERP and the future. Thus, they were more determined on the project. Due to this arbitrary choice of perspective; however, this paper is mainly limited to the discussion of intra-organizational legitimacy.

In addition, this research is a case study, so it needs to be cautious of theoretical boundaries and practical situations when the findings are applied. The logic of a case study is, however, not to prove to what extent a case can statistically represent totality but rather to reveal the concrete mechanism of a social/organizational process and to conclude from the case a number of high-quality hypotheses to be tested (Mitchell 1983; Small 2009). In this case study, I must emphasize that the technology is a platform information technology and the type of organization involved is a large Chinese state-owned conglomerate, which might help to clarify the conditions under which the conclusions are to be further inspected.

\section{Abbreviations}

ERP: Enterprise Resource Planning; CO: Controlling; Fl: Financial Module; IMO: Informatization Management Office; MM: Materials Management Module; PM: Plant Maintenance; PP: Production planning; SD: Sales and Distribution Module

\section{Acknowledgments}

I am deeply indebted to Frank Dobbin, who did a lot to help restructure the first draft. I also grateful to Zeqi Qiu, Yong Gao, Fuwei Wang, and the peer reviewers for their enlightening comments and suggestions for this paper's revisions.

\section{Authors' contributions}

This study is an independent composition. The author read and approved the final manuscript.

Funding

This study is funded by the National Social Science Fund (Project No. FSH0001).

\section{Availability of data and materials}

The data, mainly qualitative interview manuscripts used in the paper, are reserved by the author, contact the author by renmint@163.com if needed.

\section{Competing interests}

The author declares that there are no competing interests.

Received: 22 June 2019 Accepted: 4 September 2019

Published online: 12 November 2019

\section{References}

Aladwani, A.M. 2001. Change management strategies for successful ERP implementation. Business Process Management Journal 7 (3): 266-275.

Barley, S.R. 1986. Technology as an occasion for structuring: Evidence from observations of CT scanners and the social order of radiology departments. Administrative Science Quarterly 31 (1): 78-108.

Bergek, A., S. Jacobsson, B. Carlsson, S. Lindmark, and A. Rickne. 2008a. Analyzing the functional dynamics of technological innovation systems: A scheme of analysis. Research Policy 37 (3): 407-429.

Bergek, A., S. Jacobsson, and B.A. Sandén. 2008b. 'Legitimation' and 'development of external economies': Two key processes in the formation phase of technological innovation systems. Technology Analysis \& Strategic Management 20 (5): 575-592.

Brown, Andrew D. 1995. Managing understandings: Politics, symbolism, niche marketing and the quest for legitimacy in IT implementation. Organization Studies 16 (6): 951-969.

Brown, Andrew D. 1998. Narrative, politics and legitimacy in an IT implementation. Journal of Management Studies. 35 (1): 35-58.

Davis, F.D. 1986. A technology acceptance model for empirically testing new end-user information systems: Theory and results. Doctoral dissertation. Sloan School of Management. Massachusetts Institute of Technology.

Davis, F.D. 1989. Perceived usefulness, perceived ease of use, and user acceptance of information technology. MIS Quarterly 13 (3): 319-340.

Davis, F.D., R.P. Bagozzi, and P.R. Warshaw. 1989. User acceptance of computer technology: A comparison of two theoretical models. Management Science 35 (8): 982-1003.

Davison, R. 2002. Cultural Complications of ERP. Communications of the ACM. 45 (7) 109-111.

Finney, S., and M. Corbett. 2007. ERP implementation: A compilation and analysis of critical success factors. Business Process Management Journal 13 (3): 329-347.

Gao, Bingzhong. 2000. The legality of social groups. Social Sciences in China 2: 100-109.

Grint, K., and S. Woolgar. 1997. The machine at work: Technology, work and society. Cambridge: Polity Press.

Heeks, R. 2002. Information systems and developing countries: Failure, success, and local improvisations. The Information Society 18 (2): 101-112. 
Hekkert, M.P., R.A. Suurs, S.O. Negro, S. Kuhlmann, and R.E. Smits. 2007. Functions of innovation systems: A new approach for analyzing technological change. Technological Forecasting and Social Change 74 (4): 413-432.

Holland, C.P., Light, B. and Gibson, N. 1999. A critical success factors model for enterprise resource planning implementation. In Proceedings of the 7th European conference on information systems. 1: 273-287.

Hong, K.K., and Y.G. Kim. 2002. The critical success factors for ERP implementation: An organizational fit perspective. Information \& Management 40 (1): 25-40.

Huang, Xiaochun. 2010. Research on the operational mechanism of technology governance: A case study of an Egovernment center on L Street in Shanghai. Chinese Journal of Sociology 30 (4): 1-31.

Human, S.E., and K.G. Provan. 2000. Legitimacy building in the evolution of small-firm multilateral networks: A comparative study of success and demise. Administrative Science Quarterly 45 (2): 327-365.

Jones, M.C., M. Cline, and S. Ryan. 2006. Exploring knowledge sharing in ERP implementation: An organizational culture framework. Decision Support Systems 41 (2): 411-434.

Ke, W., and K.K. Wei. 2008. Organizational culture and leadership in ERP implementation. Decision Support Systems 45 (2): 208-218.

Li, Jing. 2002. Building the cultural basis for the effective use of information technology in organizations. Information Culture, Science, Technology and Engineering 6: 82-88.

Majchrzak, A., and M.L. Paris. 1995. High-performing organizations match technology and management strategies: Results of a survey. International Journal of Industrial Ergonomics 16 (4-6): 309-325.

Markard, J., S. Wirth, and B. Truffer. 2016. Institutional dynamics and technology legitimacy: A framework and a case study on biogas technology. Research Policy 45 (1): 330-344.

Martinsons, M.G. 2004. ERP in China: One package, two profiles. Communications of the ACM 47 (7): 65-68.

Mitchell, J.C. 1983. Case and situation analysis. The Sociological Review 31 (2): 187-211.

Orlikowski, W.J. 1992. The duality of technology: Rethinking the concept of technology in organizations. Organization Science 3 (3): 398-427.

Qiu, Zeqi. 2005. The mutual structuring between technology and organization: Taking the application of information technology in manufacturing enterprises as an example. Sociological Study 2: 32-54.

Qiu, Zegi. 2017. Technology and organization: Multidisciplinary research patterns and sociological concerns. Sociological Study 4: 167-192.

Rajapakse, J., and P.B. Seddon. 2005. Why ERP may not be suitable for organizations in developing countries in Asia. In Proceedings of PACIS, 1382-1388.

Rao, H. 2002. 'Tests tell': Constitutive legitimacy and consumer acceptance of the automobile: 1895-1912. Advances in Strategic Management 19: 307-335.

Ruef, M., and W.R. Scott. 1998. A multidimensional model of organizational legitimacy: Hospital survival in changing institutional environments. Administrative Science Quarterly 43 (4): 877-904.

Sarker, S., and A.S. Lee. 2003. Using a case study to test the role of three key social enablers in ERP implementation. Information \& Management 40 (8): 813-829.

Scott, W.R. 2008. Institutions and organizations: Ideas and interests. 4th ed. London: Sage.

Seo, G. 2013. Challenges in implementing enterprise resource planning (ERP) system in large organizations: Similarities and differences between corporate and university environment. Doctoral dissertation, Massachusetts Institute of Technology.

Skok, W., and M. Legge. 2002. Evaluating enterprise resource planning (ERP) systems using an interpretive approach. Knowledge and Process Management 9 (2): 72-82.

Small, M.L. 2009. How many cases do I need? On science and the logic of case selection in field-based research. Ethnography 10 (1): $5-38$.

Suchman, M.C. 1995. Managing legitimacy: Strategic and institutional approaches. The Academy of Management Review 20 (3): $571-610$

Tan, H., Q. Meng, and N. Zhang. 2015. Research on government operation mechanism in information technology application. Sociological Study 6: 73-98.

Tatnall, A. 2011. Innovation translation, innovation diffusion and the technology acceptance model: Comparing three different approaches to theorizing technological innovation. In Actor-network theory and technology innovation: advancements and new concepts, ed. A. Tatnall, 52-66. Hershey: IGI Global.

Venkatesh, V. 2000. Determinants of perceived ease of use: Integrating control, intrinsic motivation and emotion into the technology acceptance model. Information Systems Research 11 (4): 342-365.

Wang, D., and Y. Zhang. 2012. Concept definition and research context analysis of organizational legitimacy. Seeking 10: 8-10.

Wang, X. 2009. Technology hierarchy structure of FAW company and the changes of relationship between departments. Doctoral dissertation, Peking University.

Yang, H., and D. Zhao. 2013. Performance legitimacy and China's economic miracle. Study Sea 3: 16-31.

Yin, G., and W. Chen. 2009. Empirical research on enterprise information technology capabilities and its impact on informatization success - Based on RBV theory perspective. Nankai Management Review 4: 152-160.

Yusuf, Y., A. Gunasekaran, and M.S. Abthorpe. 2004. Enterprise information systems project implementation: A case study of ERP in Rolls-Royce. International Journal of Production Economics 87 (3): 251-266.

Zammuto, R.F., T.L. Griffith, A. Majchrzak, D.J. Dougherty, and S. Faraj. 2007. Information technology and the changing fabric of organization. Organization Science 18 (5): 749-762.

Zhang, J., and X. Zhu. 2016. Responsibility distribution and interaction between upper and lower levels within government - Taking safety production management of S City as an example. Journal of Social Development 3: 108-128.

Zhang, Y. 2009. Three perspectives on the relationship between technology and organization. Sociological Study 2: 200-215.

Zhen, Shao, Y. Feng, and L. Liu. 2012. The mediating effect of organizational culture and knowledge sharing on transformational leadership and enterprise resource planning systems success: An empirical study in China. Computers in Human Behavior 28 (6): 2400-2413.

\section{Publisher's Note}

